Vol. 10 (1): 107-114 (2020)

\title{
TRITIUM IN NUCLEAR FUSION SYSTEMS
}

\author{
Ciro Alberghi ${ }^{*}$ \\ I"Polytechnic University of Torino, Energy Department "Galileo Ferraris", \\ Corso Duca degli Abruzzi 24, Torino, Italy; \\ *Corresponding author Ciro Alberghi, e-mail: ciro.alberghi@polito.it;
}

Received November 2019; Accepted December 2019; Published January 2020;

DOI: https://doi.org/10.31407/ijees10.115

\begin{abstract}
Tritium, the radioactive isotope of hydrogen, is of main interest in the research and development of fusion technology. In order to establish fusion as an energy source, tritium safety and availability must be achieved. In effect, tritium constitutes a hazard, even in low quantities, and must be handled limiting the releases to the environment. Tritium will be burn in large quantities in the event of nuclear fusion power plants, and being practically non-existent in nature, must be produced by the reactor itself. After a description of tritium radiological characteristics and hazard, the tritium breeding issue is presented, focusing particularly on the most recent European breeding blanket designs.
\end{abstract}

Keywords: Tritium, Nuclear fusion, DEMO, ITER, Breeding blanket, HCPB, WCLL, Tritium transport 